\title{
Interpretation of the Effects of Job Satisfaction Meditation on the Effect of Principal Supervision and Compensation on Teacher Performance
}

\author{
Sherly $^{1}$, Darwin Lie ${ }^{2}$, Vivi Candra ${ }^{3}$, Dolly Miduk Siallagan ${ }^{4}$, Acai Sudirman ${ }^{5 *}$ \\ ${ }^{1}$ Program Studi Manajemen, Sekolah Tinggi Ilmu Ekonomi Sultan Agung, Indonesia \\ Email: sherly@stiesultanagung.ac.id \\ ${ }^{2}$ Program Studi Manajemen ,Sekolah Tinggi Ilmu Ekonomi Sultan Agung, Indonesia \\ Email: darwin@stiesultanagung.ac.id \\ ${ }^{3}$ Program Studi Manajemen ,Sekolah Tinggi Ilmu Ekonomi Sultan Agung, Indonesia \\ Email: vivicandra@stiesultanagung.ac.id \\ ${ }^{4}$ Program Studi Magister Ilmu Manajemen, Sekolah Tinggi Ilmu Ekonomi Sultan Agung, Indonesia \\ Email: dollysiallagan5@gmail.com \\ ${ }^{5}$ Program Studi Manajemen ,Sekolah Tinggi Ilmu Ekonomi Sultan Agung, Indonesia \\ Email: acaivenly@stiesultanagung.ac.id
}

(Received: 08-02-2021; Reviewed: 17-03-2021; Accepted: 19-04-2021; Available online: 21-04-2021; Published: 25-04-2021)

This is an open access article distributed under the Creative Commons Attribution License CC-BY-NC-4.0 (C) 2021 by author (https://creativecommons.org/licenses/by-nc/4.0/).

\begin{abstract}
This research aims to determine the role of job satisfaction as a mediator of the relationship between principal supervision and compensation for teacher performance. The research design used a quantitative approach to causality. To obtain research data using documentation instruments and distributing questionnaires online. The sample used in the study was 215 respondents. The basis for determining the sample is oriented towards a nonprobability sampling approach using a purposive sampling formula. To test the mediating effect of satisfaction and the relationship between principal supervision and compensation on teacher performance, a structural equation modeling (SEM) approach is used using partial least squares. Under the research results, It was found that the fact that principal supervision had a significant effect on job satisfaction and teacher performance. Then compensation also has a significant effect on job satisfaction and teacher performance. The findings of the mediation effect state that job satisfaction successfully mediates the relationship between principal supervision and compensation for teacher performance. Furthermore, this study's novelties are to place job satisfaction as a mediating variable on the relationship between principal supervision and compensation to teacher performance, where previous research has not yet presented a research model as presented in this study.
\end{abstract}

Keywords: principal supervision, compensation, job satisfaction, teacher performance

\section{INTRODUCTION:}

In today's era of globalization, the role of education is very important, because it is a forum for forming quality human resources to compete globally (Widayati, Fitria, and Fitriani 2020). In supporting the advancement of education in Indonesia, it is hoped that teachers will become role models in making changes in schools performance (Lie et al., 2019). The quality of teacher performance will greatly determine the quality of educational outcomes (Pakpahan et al., 2019) because teachers are the ones who have the most direct contact with students in the education/learning process in school education institutions (Darmawati, 
Munjin, and Seran 2015). Performance or job performance is defined as an indication of the capacity to achieve something based on experience, behaviors, abilities and motivation (Harum, Manullang, and Hartiwi 2015). However, problems in the field of education have never subsided, for example; at the education unit level, there are still principals who do not carry out their function as supervisors (Virgana 2014).

Based on the results of field observations and additional information in the form of interviews from several sources related to the object of research, it was found that the implementation of supervision carried out by the principal was still not optimal. This is because the principal wants to conduct systematic unscheduled supervision when he wants to supervise teacher performance. So that the majority of teachers do not have a full sense of responsibility for their work due to the inconsistency of the follow-up of the supervision, of course, this contradicts the findings of Husnidar, Afandi, and Darwis (2020), which concluded that the implementation of the supervision of a school principal has a significant impact on the level of job satisfaction and the implication is that it will improve the performance of a teacher.

The principal as a supervisor is in charge of providing professional assistance and guidance to teachers who lack professional skills in teaching (Ghautama 2015). This is following the nature of supervision which is an effort to provide services so that teachers become more professional (Yohanas 2018). At least half of the principal's time should be planned for supervisory activities (Rifaldi and Roesminingsih 2014). Findings Sarjana (2012), Rifaldi and Roesminingsih (2014), Husnidar, Afandi, and Darwis (2020), convey that the job satisfaction of a teacher is strongly influenced by the supervision applied by the principal. However, the research results Yohanas (2018) and Wiguna and Suputra (2016), conclude that contradicts the previous findings which state there is no significant effect of the supervision provided by the principal on job satisfaction.

Principal supervision is an effort to guide so that teachers can improve the quality of learning by going through lesson planning steps and real teaching performances (Wibowo 2014). The inability of a teacher to use various learning methods that are attractive to students provides an opportunity for the principal to play more roles active by carrying out academic supervision well (Pujianto, Arafat, and Setiawan 2020). Findings Wahyudi, Thomas, and Setiyani (2014), Ramadona and Wibowo (2016), Aprida, Fitria, and Nurkhalis (2020), conveying that the performance displayed by a teacher is strongly influenced by the supervision applied by the principal. However, the research results Amanda, Salam, and Saggaf (2017) and Hazli and Saputra (2019), concluded things that are different from previous findings, that there is no significant effect of the supervision given by the head school on teacher performance.

Compensation is one of the important functions of human resource management. In principle, compensation is the result of sales of human resources to companies and organizations (Pertiwi et al. 2019). One way to get teachers to be active in carrying out their duties is by providing compensation in the form of allowances and other facilities (Muliati, Sudirman, and Fahruddin 2020). Findings (Hakim and Muhdi 2019), (Rasyid and Tanjung 2020), (Suyusman, Hendro, and Asiati 2020), conveying that a teacher's job satisfaction is strongly influenced by the amount of compensation received. However, the research results (Suhardi and Yunita 2018) and (Mawei, Uhing, and Nelwan 2014), concluded that there is no significant effect of compensation on job satisfaction.

Findings from research results (Handayani 2015), (Ratnawati 2018), (Imroatun and Sukirman 2016), conveyed that the level of effectiveness of a teacher's performance is strongly influenced by the amount of compensation received. Things that are often done by schools related to worker's compensation are the awarding of teachers who excel. Every teacher always wants to be given better worker's compensation when they can complete work optimally (Muliati et al. 2020). The provision of compensation aims to help employees meet needs beyond the need for fairness, as well as increase teacher work motivation in completing tasks that are their responsibility (Pitri 2017). However, the research results (Risqon and Purwadi 2012) and (Arifin 2017), concluded that in contrast to the previous findings, there was no significant effect of giving compensation for teacher performance.

In addition to the factor of principal supervision and provision of compensation, job satisfaction is a strategic factor in the development of education in schools (Narsih 
2017). Reflections on job satisfaction are closely related to a person's attitude towards his job, the greater the level of job satisfaction will encourage a person's attitude towards a better way of doing his job (Sofyan, Prasada, and Akbar 2020). Findings Pratiwi (2013), Iskandar and Juhana (2014), Pamungkas and Jabar (2014), conveying the performance of a teacher is strongly influenced by the job satisfaction obtained. However, the research results Arifin (2017) and Ghozali (2017), concluded that contradicting the previous findings which stated there was no significant effect of the acquisition of job satisfaction on performance.

The novelty element of this research lies in the measurement of teacher performance variables which are oriented towards the indicators of teacher performance appraisal carried out on three learning activities in the classroom, namely: planning learning activity programs, implementing learning activities, evaluating/assessing learning "(Law No. 14 of 2005 about teachers and lecturers). Simultaneously, several other studies use assessment indicators based on the Minister of National Education Regulation number 16 of 2007 concerning academic qualification and competency standards consisting of 14 teacher performance assessment indicators (Aprida, Fitria, and Nurkhalis 2020).

The urgency of this study departs from several previous findings that state different results, so it is important to carry out further research related to the relationship of principal supervision and compensation to teacher performance by including job satisfaction as a mediating variable. The purpose of this study was to determine the effect of principal supervision and compensation on teacher performance with job satisfaction as a mediator. Through the results of this study, it is hoped that it can provide information that is relevant to the topic of research as well as a significant contribution to academics, schools and the education office in the decision making process.

\section{METHOD}

The data collected in this study are quantitative data. This research was conducted at a private junior high school, Pematangsiantar City, North Sumatra. This research was conducted for 3 months, from May to July 2020. This time was used for data collection, both instrument trial data, and research data. The population in this study were all permanent teachers with the status of private teachers in all private junior high schools in Pematangsiantar City with a total of 320 teachers. The research sample consisted of 215 teachers who were assigned a purposive sampling technique. The measurement of the dependent variable, namely teacher performance is measured using the Law of the Republic of Indonesia number 14 of 2005 concerning Teachers and Lecturers which consists of 3 indicators. Furthermore, the first independent variable, namely the supervision of the principal, was measured using previous research Rismawan (2015) \& Maulid (2017), which consists of 3 indicators. The second independent variable, namely compensation is measured using previous research Suyusman et al. (2020), which consists of 5 indicators. Then for the mediating variable, namely job satisfaction is measured using previous references Iskandar and Juhana (2014), which consists of 6 indicators. Furthermore, the framework and hypothesis development in this study can be explained as follows figure 1 .

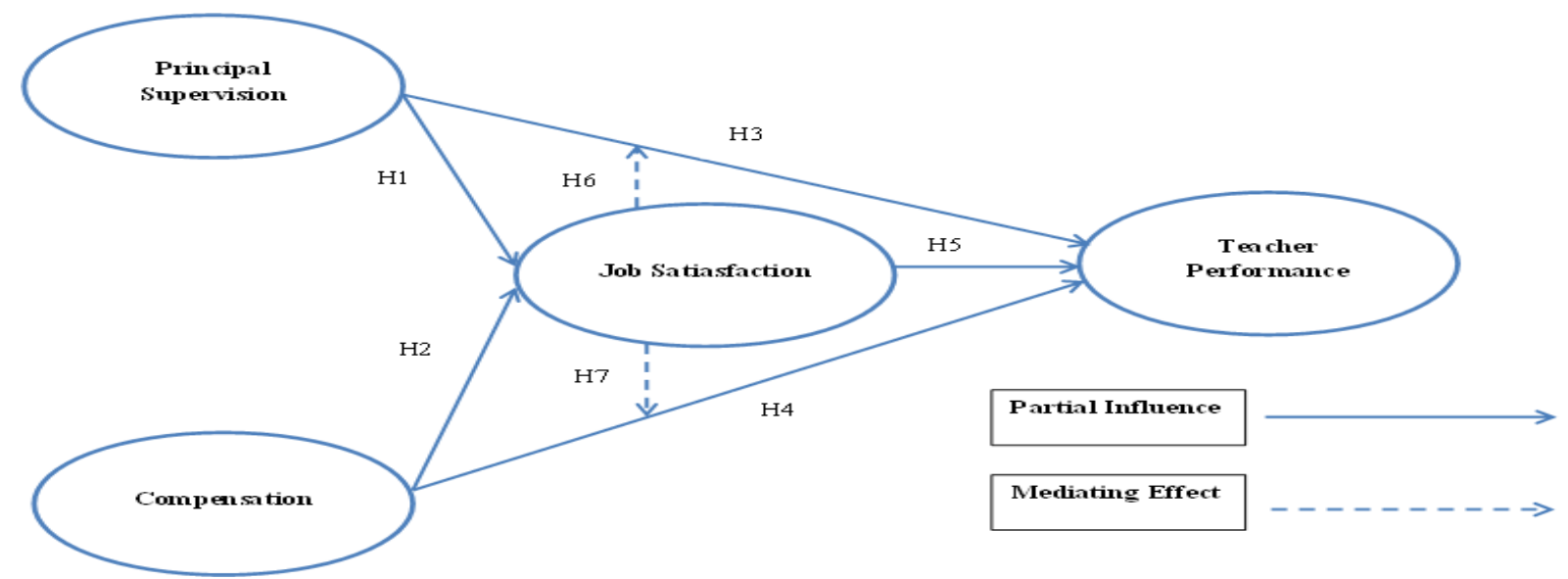

Figure 1. Framework 
Based on Figure 1 above which is the framework in this study, several research hypotheses can be formulated, including:

H1: Principal supervision affects the job satisfaction

$\mathrm{H} 2$ : Compensation affects the job satisfaction

H3: Compensation affects teacher performance

H4: Compensation affects teacher performance

H5: Job satisfaction affects teacher performance

H6: Job satisfaction mediates the relationship between the supervision of the principal on teacher performance

H7: Job satisfaction mediates the relationship between compensation and teacher performance

\section{RESULTS AND DISCUSSION}

\section{Result}

Based on the findings of the recapitulation of the responses of the respondents who completed the online questionnaire, 320 respondents entered the data, but only 215 respondents validly completed the data. The general characteristics of respondents in this study are clearly described in table 1 below:

Table 1. General Profile of Respondents

\begin{tabular}{cccc}
\hline Category & Detail & total & Percentage \\
\hline \multirow{2}{*}{ Gender } & Men & 92 & $42.79 \%$ \\
& Woman & 123 & $57.21 \%$ \\
\hline \multirow{4}{*}{ Age } & 20-29 years & 38 & $17.67 \%$ \\
& 30-39 years & 95 & $44.19 \%$ \\
& 40-49 years & 53 & $24.65 \%$ \\
& $50-59$ years & 29 & $13.49 \%$ \\
& 20-29 years & 38 & $17.67 \%$ \\
\hline \multirow{4}{*}{ Level of } & High school & 7 & $3.26 \%$ \\
education & D1 to D3 & 54 & $25.12 \%$ \\
& Bachelor & 133 & $61.86 \%$ \\
& Masters & 21 & $9.76 \%$ \\
\hline \multirow{4}{*}{ Years of } & $<1$ year & 12 & $5.58 \%$ \\
service & 1-5 Years & 16 & $7.44 \%$ \\
& 6-10 Years & 44 & $20.47 \%$ \\
& $>10$ Years & 143 & $66.51 \%$ \\
\hline
\end{tabular}

Source: processed data (2020)

\section{Outler Model Measurement}

In measuring the outer model, the tests carried out are validity tests and reliability tests. Convergent validity testing is determined by the loading factor and AVE with the condition that the loading factor is above 0.7 and the AVE value is 0.5 (Hair 2014). Model reliability testing according to Hair (2014), seen from the value of cronbanch's alpha and composite reliability (CR) which has a value greater than 0.7. The following will display an explanation of the measurement of the outler model which is presented using table 2 .

Table 2. Outler Model Measurement Results

\begin{tabular}{lcccc}
\hline $\begin{array}{c}\text { Construct / } \\
\text { item }\end{array}$ & $\begin{array}{c}\text { Outler } \\
\text { Loading } \\
\text { s }\end{array}$ & $\begin{array}{c}\text { Cronb } \\
\text { ach } \\
\text { 'alpha }\end{array}$ & CR & $\begin{array}{c}\text { AV } \\
\text { E }\end{array}$ \\
\hline $\begin{array}{l}\text { Supervision of } \\
\text { the Principal }\end{array}$ & & 0.922 & 0.94 & 0.86 \\
& & & 9 & 2 \\
SK1 & 0.930 & & & \\
SK2 & 0.950 & & & \\
SK3 & 0.906 & & & \\
\hline Compensation & & 0.941 & 0.95 & 0.80 \\
& & & 5 & 9 \\
KP1 & 0.904 & & & \\
KP2 & 0.880 & & & \\
KP3 & 0.882 & & & \\
KP4 & 0.927 & & & \\
KP5 & 0.904 & & & 0.70 \\
\hline Job & & 0.915 & 0.93 & 0.70 \\
satisfaction & & & 4 & 3 \\
KK1 & 0.894 & & & \\
KK2 & 0.839 & & & \\
KK3 & 0.895 & & & \\
KK4 & 0.827 & & & \\
KK5 & 0.763 & & & \\
KK6 & 0.806 & & & \\
\hline Teacher & & 0.813 & 0.88 & 0.72 \\
Performance & & & & 6 \\
KG1 & 0.883 & & & \\
KG2 & 0.886 & & & \\
KG3 & 0.782 & & & \\
\hline Source: processed data (2020) & & & \\
& & & &
\end{tabular}

In the validity test presented in table 2 above, it is known that the value of each loading factor on the variable indicator of school principal supervision, compensation, job satisfaction, and teacher performance is above 0.7 and above 0.5 for the average variance extracted value. (AVE). In addition, as calculated by the composite reliability value and 
the Cronbach alpha value, the value for each variable is above 0.7 , implying that all study variables have a strong reliability value for each variable. With this good value, it can be used as an illustration of the condition that the relationship between variables is also good so that further tests can be carried out.

\section{Inner Model Measurement}

Inner model measurement is done by bootstrapping research data using SmartPLS 3.2.9. There are two results obtained from bootstrapping, the first is the significance of the two related variables, and also the R-square of the study. The value of the R-square is a value that shows the ability of exogenous variables to build endogenous variables. According to (Chin, Peterson, and Brown 2008), there are three categories of R-square values if the R-square value is 0.19 , the relationship between exogenous variables forming endogenous variables is weak, if it is 0.33 it means the relationship is moderate and if the value is 0.67 it indicates that the relationship is strong. While Sarwono (2016), states that if the R-square value is more than 0.67, the relationship between endogenous and exogenous is very strong. The explanation of the results of the calculation of the R-square value can be seen in Table 3 .
Table 3. Results of the calculation of the value of R-Square

\begin{tabular}{ccc}
\hline Information & $R$ Square & $R$ Square Adjusted \\
\hline Job satisfaction & 0.212 & 0.205 \\
\hline $\begin{array}{c}\text { Teacher } \\
\text { Performance }\end{array}$ & 0.328 & 0.318 \\
\hline Source: processed data $(2020)$ &
\end{tabular}

Source: processed data (2020)

Judging from the R-square value for the first endogenous variable, namely ape satisfaction, the score is 0.212 and the teacher's performance is 0.328 , which is below 0.33 , this shows that overall the ability of exogenous variables to explain endogenous variables is weak. In addition, a significance test is used to assess the relationship between exogenous variables and endogenous variables to illustrate the hypothesis test. The importance criterion is seen from the $p$-value. If the $p$-value between exogenous and endogenous variables is less than 0.05 , with a significance level of 5 percent, it means that the exogenous variable has a substantial influence on endogenous variables, on the opposite, if the value is greater than 0,05 means that the exogenous variables do not have a major effect on the endogenous variables construction. The following shows the results of the hypothesis test which are described in Figure 2 and Table 4.

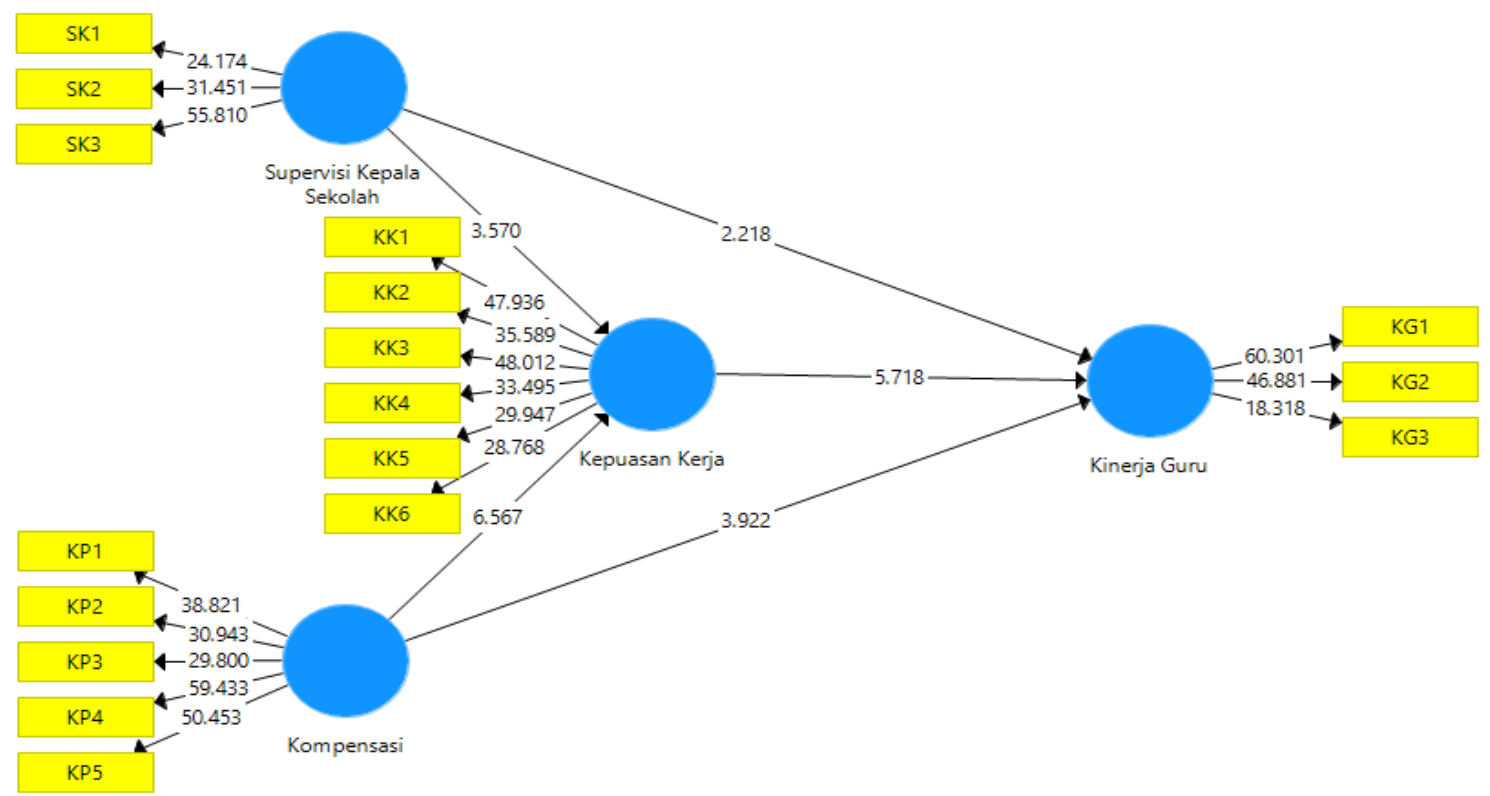

Figure 2. Inner Model Analysis Results 
Table 4. Path Coefficients Test Results

\begin{tabular}{|c|c|c|c|c|}
\hline Path Between Variables & Coefficient & thitung & P-Value & Conclusion \\
\hline $\begin{array}{c}\text { Supervision of the principal }>>\text { Job } \\
\text { satisfaction }\end{array}$ & 0.228 & 3,570 & 0.000 & Received \\
\hline Compensation $>>$ Job satisfaction & 0.382 & 6,567 & 0.000 & Received \\
\hline $\begin{array}{c}\text { Supervision of the principal }>>\text { Teacher } \\
\text { Performance }\end{array}$ & 0.141 & 2,218 & 0.027 & Received \\
\hline Compensation $>>$ Teacher Performance & 0.248 & 3,922 & 0.000 & Received \\
\hline Job Satisfaction $>>$ Teacher Performance & 0.373 & 5,718 & 0.000 & Received \\
\hline
\end{tabular}

Source: processed data (2020)

Based on the processed data presented in table 4 above, the significance test of the direct relationship between exogenous and endogenous variables can be said that overall exogenous variables have a significant effect on endogenous variables. Of the 5 hypotheses developed partially, it is known that the supervision of the principal has a significant effect on job satisfaction. Compensation has a significant effect on job satisfaction. Then, the supervision of the principal has a significant effect on teacher performance. Compensation has a significant effect on teacher performance. Furthermore, it is known that job satisfaction has a significant effect on teacher performance. Furthermore, to determine the mediating effect of job satisfaction on the relationship between principal supervision and compensation on teacher performance.

Table 5. Mediation Test Results Based on Indirect Effect

\begin{tabular}{ccccc}
\hline Path Between Variables & Coefficient & thitung & P-Value & Conclusion \\
\hline $\begin{array}{c}\text { Principal Supervision }>>\text { Job Satisfaction }>> \\
\text { Teacher Performance }\end{array}$ & 0.085 & 3,171 & $\mathbf{0 . 0 0 0}$ & Mediate \\
$\begin{array}{c}\text { Compensation }>>\text { Job Satisfaction }>>\text { Teacher } \\
\text { Performance }\end{array}$ & 0.142 & 4,237 & $\mathbf{0 . 0 0 0}$ & Mediate \\
\hline
\end{tabular}

Source: Processed Data (2020)

Based on the results of the processed data presented in table 5 above, it can be concluded that the job satisfaction variable is able to mediate the relationship between principal supervision and teacher performance as evidenced by the acquisition of a p-value of 0,000 which is below 0.05 . Furthermore, the job satisfaction variable has also been shown to be able to mediate the relationship between compensation to teacher performance as evidenced by the acquisition of a p-value of 0,000 which is below 0.05 .

\section{Discussion}

The results showed that the supervision of the principal has a positive and significant effect on job satisfaction. The task of teachers is closely related to increasing human resources through the education sector, therefore there is a need for efforts to improve the quality of teachers to become professionals (Maisah 2020). The implementation of supervision, if carried out continuously, will provide a stimulus to one's morale so that it is expected to be able to provide a level of satisfaction following the 
expectations of the teachers. This condition illustrates that the role of the principal's supervision can encourage an increase in work culture so that every teacher who carries out the work gets maximum satisfaction. The findings of this study are consistent with the results of the study (Ghautama 2015), (Firdausi 2018), and (Pujianto et al. 2020), whose research results state that there is a significant effect between the principal's supervision of job satisfaction.

The results showed that compensation had a positive and significant effect on job satisfaction. If the compensation received by the teacher is high, the teacher will feel even more satisfied. Conversely, if the compensation received by the teacher is small, the teacher will feel dissatisfied at work(Pertiwi et al. 2019). From this statement, it is clear that there is a link between compensation and job satisfaction that with an increase in the compensation given, it will increase employee job satisfaction (Rafi et al. 2015). The results of this research are in line with the findings presented by (Robirodia and Prihatin 2016), (Okt Apii, Nurdin, and Abubakar 2018) and (Damayanti and Ismiyati 2020), whose research results state that there is a significant influence between compensation on job satisfaction.

The results of further research indicate that the supervision of the principal has a positive and significant effect on teacher performance. The implementation of supervision has the aim of fostering the work creativity of teachers in designing and implementing learning so that the implementation of comprehensive supervision is expected to be able to encourage a teacher to be more professional (Ramadan 2017). Supervised teachers will get teaching experience according to the direction of the supervisor. So, the teacher gets new experiences inside each following the instructions of the school leadership (Wibowo 2014). The findings of this study are in line with the results of the research presented by (Astuti and Dacholfany 2016), (Ramadan 2017) and (Raberi, Fitria, and Fitriani 2020), whose research results state that there is a significant influence between head supervision school on job satisfaction.

The results showed that compensation had a positive and significant effect on teacher performance. Compensation is a form of reward that an organization gives its workers as a form of remuneration for what they do (Chandra et al. 2014). Compensation is given according to the contribution made by the teacher in the school.
Providing adequate and fair compensation in the form of money (financial) and indirect (nonfinancial), provide separate motivation for teachers to work optimally to achieve school organizational goals (Syahputra et al. 2013). The results of this research are in line with the findings presented by (Syamra 2016), (Oktaviani and Nainggolan 2016), (Isnaneni 2020), whose research results state that there is a significant effect of compensation on teacher performance.

The results showed that job satisfaction has a positive and significant effect on teacher performance. The satisfaction obtained by a person has an important role in an organization, where if the satisfaction of a teacher is met, then he will work optimally for the achievement of organizational goals (Sofyan et al. 2020). A good representative of job satisfaction will be seen when there is a driving force that will encourage someone to be willing to work hard by giving all abilities and skills to achieve organizational goals (Iskandar and Juhana 2014). The results of this research are in line with the findings presented by (Ahmadiansah 2016), (Hidayat, Sridiana, and Sudirman 2016), (Kakiay 2017), whose research results state that there is a significant influence between job satisfaction obtained by a teacher on teacher performance.

In the mediation test job, satisfaction with the effect of principal supervision on teacher performance obtained significant results. This means that the better the supervision applied by the principal in the form of leadership, the level of satisfaction that will indirectly affect the level of performance (Ilmawan, Wulandari, and Fitriani 2017). The results of this research are in line with the findings presented by Wardhani and Soetomo (2017), whose research results state that job satisfaction can mediate the relationship between principal supervision in the form of leadership on teacher performance. Furthermore, in the next mediation test, results were obtained that stated job satisfaction succeeded in mediating the relationship between compensation and teacher performance. This gives confidence that the better the compensation was given to the teacher, it will be able to increase the job satisfaction of the teacher which in turn will have an indirect impact on improving teacher performance (Ilmawan and Noermijati 2016). The results of this research are in line with the findings presented by Wiratmadja and Govindaraju 
(2008), whose research results state that job satisfaction can mediate the relationship between compensation. on teacher performance.

\section{CONCLUSIONS AND SUGGESTIONS}

From the results of hypothesis testing conducted, it is known that the results of the first hypothesis testing indicate the supervision of job satisfaction. Then for the results of the second hypothesis, compensation has a positive and significant effect on job satisfaction. For the results of further research developed through the third hypothesis, it proves that the supervision of the principal has a positive and significant effect on teacher performance. Furthermore, the results of the fourth hypothesis indicate that compensation has a positive and significant impact on teacher performance. For the results of the fifth hypothesis, the results show that job satisfaction has a positive and significant effect on teacher performance.

Furthermore, The results of the mediation test prove that the job satisfaction variable can mediate the relationship between principal supervision on teacher performance and the job satisfaction variable is also proven to be able to mediate the relationship between compensation to teacher performance. Suppose the implementation of principal school supervision is carried out in a comprehensive and structured manner and is followed by the acquisition of good job satisfaction. In that case, this will encourage an increase in the performance of a teacher. Likewise, the provision of compensation following the level of performance will provide an optimal level of satisfaction.

Furthermore, this study's novelties are to place job satisfaction as a mediating variable on the relationship between principal supervision and compensation to teacher performance, where previous research has not yet presented a research model as presented in this study. This study's results show new findings related to job satisfaction, which can mediate the relationship between principal supervision and compensation for teacher performance. The limitation of this research lies in the number of samples and the number of predictor variables used. For further research, it is necessary to increase the sample size by selecting a wider research object so that generalizations can be made and increasing the number of predictor variables, such as organizational culture, work environment, teacher certification, competence, and others.

\section{ACKNOWLEDGMENT}

On this occasion, the authors would like to thank the Head of the Sultan Agung School of Economics for permitting us to carry out research activities. Pematangsiantar City Education Office has facilitated the author during carrying out research activities. All principals and teachers of Private Junior High School (SMP) Pematangsiantar City who are willing to respond to the questionnaire given as well as all authors who have contributed from the beginning of the study to the end of this study.

\section{REFERENCES}

Ahmadiansah, Reza. 2016. "Pengaruh Motivasi Kerja Dan Kepuasan Kerja Terhadap Kinerja Guru Smk Muhammadiyah Salatiga." Inject: Interdisciplinary Journal of Communication 1(2):223-36.

Amanda, Mentari Ocvilia, Rudi Salam, and Said Saggaf. 2017. "Pengaruh Supervisi Kepala Sekolah Terhadap Kinerja Guru Di SMK Negeri 1 Bungoro Kabupaten Pangkep." Prosiding Seminar Nasional Himpunan Sarjana Ilmu-Ilmu Sosial 2:149-54.

Aprida, Yopi, Happy Fitria, and Nurkhalis. 2020. "Pengaruh Supervisi Kepala Sekolah Dan Motivasi Kerja Guru Terhadap Kinerja Guru." Journal of Education Research 1(2):160-64.

Arifin, Muhammad. 2017. "Pengaruh Kompensasi Dan Kepuasan Kerja Terhadap Kinerja (Studi Terhadap Fakultas Keguruan Dan Ilmu Pendidikan Universitas Muhammadiyah Sumatera Utara)." Jurnal EduTech 3(2):2442-6024.

Astuti, Rubiyah, and M. Ihsan Dacholfany. 2016. "Pengaruh Supervisi Pengawas Sekolah Dan Kepemimpinan Kepala Sekolah Terhadap Kinerja Guru Smp Di Kota Metro Lampung." Jurnal Lentera Pendidikan Pusat Penelitian Lppm Um Metro 1(2):204-17.

Chandra, Febrina, Darwin Lie, Marisi Butarbutar, and Efendi Efendi. 2014. "Pengaruh Kompetensi Guru Terhadap Kinerja Guru Pada Sekolah Dasar Perguruan Kristen Kalam Kudus ILearning Pematangsiantar." Sultanist: 
Jurnal Manajemen Dan Keuangan 2(1):18.

Chin, Wynne W., Robert A. Peterson, and Steven P. Brown. 2008. "Structural Equation Modeling In Marketing: Some Practical Reminders Structural Equation Modeling In Marketing : Some Practical Reminders." Journal of Marketing Theory and Practice ISSN: 16(4):287-98.

Damayanti, Evi, and Ismiyati. 2020. "Pengaruh Kompensasi, Lingkungan Kerja, Dan Budaya Organisasi Terhadap Kepuasan Kerja Guru." Economic Education Analysis Journal 9(1):33-49.

Darmawati, Darmawati, R. Akhmad Munjin, and G. Goris Seran. 2015. "Pengaruh Supervisi Kepala Sekolah Terhadap Kinerja Guru Di Smp Negeri 1 Parung Kecamatan Parung Kabupaten Bogor." Jurnal Governansi 1(1):13.

Firdausi, Annas. 2018. "Pengaruh Supervisi Dan Kepercayaan Diri Terhadap Kepuasan Kerja Guru SMKN Di Jakarta Timur." Jurnal SAP 2(3):270-78.

Ghautama, Wisnu Satria. 2015. "Pengaruh Supervisi Akademik Kepala Sekolah, Iklim Kerja Sekolah Dan Disiplin Kerja Terhadap Kepuasan Kerja Guru Slb Se Kota Yogyakarta Tahun Ajaran 2013/2014." Jurnal Penelitian Evaluasi Dan Pendidikan 3(3):125-32.

Ghozali, Imam. 2017. "Pengaruh Motivasi Kerja, Kepuasan Kerja Dan Kemampuan Kerja Terhadap Kinerja Pegawai Pada Kantor Kementrian Agama Kabupaten Banjar." Jurnal Ilmiah Ekonomi Bisnis 3(1):130-37.

Hair, J. F. 2014. Multivariat Data Analysis 7th Edition. New Jersey: Pearson Prentice Hall.

Hakim, Arif Rahman, and Muhdi Muhdi. 2019. "Motivasi Kerja Dan Kompensasi Terhadap Kepuasan Kerja Guru Smk Swasta Di Wilayah Timur Kabupaten Pemalang." Jurnal Pendidikan Ilmu Sosial 29(2):105-15.

Handayani, Trisni. 2015. "Pengaruh Kompensasi Terhadap Kinerja Guru." Utilitas 1(1):2434.

Harum, Welianus, Rizal R; Manullang, and
Devina Clearesta Hartiwi. 2015. "Analisis Pengaruh Kepuasan Kerja Dan Motivasi Kerja Terhadap Kinerja Guru (Studi Kasus Di KB-TK-SD Santa Theresia I Pangkalpinang)." Ilmiah Progresif Manajemen Bisnis 8(2):44-54.

Hazli, Hazli, and Rendy Rinaldy Saputra. 2019. "Analisis Pengaruh Supervisi Pengawas Dan Supervisi Kepala Sekolah Terhadap Kinerja Guru Di Madrasah Ibtidaiyah Kecamatan Sukau Lampung Barat." Jurnal Publikasi Pendidikan 9(1):62-68.

Hidayat, Ramli, Nyoman Sridiana, and Sudirman. 2016. "Pengaruh Kepuasan Kerja Dan Komitmen Organisasi Terhadap Kinerja Guru SMK Negeri Di Kota Mataranm." Jurnal Ilmiah Profesi Pendidikan 1(2):198-210.

Husnidar, Muslim Afandi, and Amri Darwis. 2020. "Pengaruh Supervisi Dan Kepemimpinan Kepala Madrasah Terhadap Kepuasan Kerja Tenaga Pendidik Madrasah Tsanawiyah Se Kecamatan Perhentian Raja." Indonesian Journal of Islamic Educational Management 3(1):3343.

Ilmawan, Mirza Dwinanda, and Noermijati Noermijati. 2016. "Peran Kompensasi Dan Karakteristik Leadership Pada Kinerja Guru Yang Dimediasi Oleh Kepuasan Kerja." Jurnal Ekonomi MODERNISASI 12(2):51.

Ilmawan, Mirza Dwinanda, Dwi Setia Wulandari, and Fatmala Fitriani. 2017. "Peran Gaya Kepemimpinan Dan Kompensasi Dalam Mempengaruhi Kinerja Yang Dimediasi Oleh Kepuasan Kerja." Jurnal Ekonomi Modernisasi 13(1):37.

Imroatun, Siti, and Sukirman. 2016. "Pengaruh Lingkungan Kerja, Kompensasi Kerja, Dan Motivasi Kerja Terhadap Kinerja Guru Ekonomi/ Akuntansi Di Sma Negeri SeKabupaten Wonosobo." Economic Education Analysis Journal 5(1):181-94.

Iratmadja, Iwan Inrawan and Rajesri, Govindaraju. (2008). The Influence of Transformational Leadership Style and Compensation System on the Performance of University Lecturer, a Case at a State University in Indonesia. Proceedings of the 9th Asia Pasific 
Industry Engineering and Management Systems Conference, APIEMS 2008, Nusa Dua, Bali, Indonesia. December 3rd-5th. pp. 693-698

Iskandar, Sentot, and Enceng Juhana. 2014. "Pengaruh Kompetensi Dan Lingkungan Kerja Terhadap Kepuasan Kerja Serta Implikasinya Pada Kinerja Guru Di SDN Baros Mandiri 5 Kota Cimahi." Jurnal Ekonomi, Bisnis \& Entrepreneurship 8(2):86-98.

Isnaneni, Devi Putri. 2020. "Pengaruh Kompensasi Dan Motivasi Kerja Terhadap Kinerja Guru Pns Sd Negeri." KREATIF : Jurnal Ilmiah 8(2):15-28.

Kakiay, Agustina N. 2017. "Pengaruh Kepemimpinan Spiritual Dan Kepuasan Kerja Terhadap Kinerja Guru Performance." Jurnal Psikologi 10(2):14851.

Lie, D., Sherly, S., Dharma, E., \& Sudirman, A. (2019). The Impact of Work Discipline and Work Ethic on the Teacher Performance of Sultan Agung Pematangsiantar Private Middle School Teachers T.A. 2018/2019. International Journal of Business Studies, 3(3), $125-135$. https://doi.org/10.32924/ijbs.v3i3.83

Maisah. 2020. "Implementasi Supervisi Kepala Sekolah Dengan Teknik Kelompok ( Meeting ) Dalam Meningkatkan Kinerja Guru MI Nurul Ulum Pegiringan Bantarbolang Pemalang." Indonesia Journal of Educationalist 1(3):333-42.

Maulid, Ahmad. 2017. "Pengaruh Supervisi Kepala Sekolah Dan Pengembangan Tenaga Pendidik Terhadap Kinerja Guru Madrasah Aliyah Swasta Di Kabupaten Lima Puluh Kota." JMKSP (Jurnal Manajemen, Kepemimpinan, Dan Supervisi Pendidikan) 1(2):89-98.

Mawei, Aprilia Christy, Yantje Uhing, and Olivia Nelwan. 2014. "Kepemimpinan, Penempatan Kerja Dan Kompensasi Pengaruhnya Terhadap Kepuasan Kerja Pada Pt. Bank Bni (Persero), Tbk. Kcu Manado." EMBA 2(2):944-54.

Muliati, Sudirman, and Fahruddin. 2020. "Pengaruh Kompensasi Kerja Terhadap Kinerja Guru SD Negeri Di Kecamatan Narmada." Jurnal Praktisi Administrasi
Pendidikan 4(2):0-4.

Narsih, Dwi. 2017. "Pengaruh Kompetensi Dan Kepuasaan Kerja Terhadap Kinerja Guru SMKN 23 Jakarta Utara." Utility: Jurnal Ilmiah Pendidikan Dan Ekonomi 1(1):94102.

Oktapiani, Rani, Diding Nurdin, and Abubakar. 2018. "Kompensasi Dan Iklim Organisasi Sekolah Terhadap Kepuasan Kerja Guru Sekolah Dasar." Jurnal Administrasi Pendidikan 25(1):140-49.

Oktaviani, Rina, and Kaman Nainggolan. 2016. "Analisis Pengaruh Kompensasi Dan Lingkungan Kerja Terhadap Kinerja Guru Di Sma Negeri 1 Klaten." Ecodemica 4(2):136-45.

Pakpahan, G. E., Nababan, S., Simanjuntak, J., \& Sudirman, A. (2019). Pengaruh budaya organisasi, komunikasi dan kompetensi guru terhadap kinerja guru sma swasta sultan agung pematangsiantar. Jurnal Kinerja, 16(2), 131-138.

Pamungkas, Widyanggoro, and Cepi S. Abdul Jabar. 2014. "Pengaruh Profesionalitas, Kepuasan Kerja Dan Iklim Organisasi Terhadap Kinerja Guru Smkn Di Kabupaten Boyolali." Jurnal Akuntabilitas Manajemen Pendidikan 2(2):265-78.

Pertiwi, Yulia, Efendi Efendi, Andy Wijaya, and Sudung Simatupang. 2019. "Pengaruh Komunikasi Interpersonal Dan Kompensasi Terhadap Kepuasan Kerja Pada Pt Perkebunan Nusantara Iii (Persero) Kebun Bangun." SULTANIST: Jurnal Manajemen Dan Keuangan 7(2):11-20.

Pitri, Alisyah. 2017. "Pengaruh Kompensasi Terhadap Kinerja Guru Di Smp Negeri 3 Batusangkar." JMKSP (Jurnal Manajemen, Kepemimpinan, Dan Supervisi Pendidikan) 2(1):1-11.

Pratiwi, Suryani Dewi. 2013. "Pengaruh Motivasi Kerja, Kepuasan Kerja, Kepemimpinan Kepala Sekolah Menurut Persepsi Guru, Dan Iklim Sekolah Terhadap Kinerja Guru Ekonomi SMP Negeri Di Kabupaten Wonogiri." JPIM: Jurnal Pendidikan Insan Mandiri 1(1):90 100.

Pujianto, Pujianto, Yasir Arafat, and Andi Arif Setiawan. 2020. "Pengaruh Supervisi Akademik Kepala Sekolah Dan 
Lingkungan Kerja Terhadap Kinerja Guru Sekolah Dasar Negeri Air Salek." Journal of Education Research 1(2):106-13.

Raberi, Ariyadi, Happy Fitria, and Yessi Fitriani. 2020. "Pengaruh Supervisi Kepala Sekolah Dan Peran Komite Sekolah Terhadap Kinerja Guru.” Jurnal Al - Qiyam 1(2):110.

Rafi, M., Darwin Lie, Marisi Butarbutar, and Efendi Efendi. 2015. "Pengaruh Motivasi Dan Kompensasi Terhadap Kepuasan Kerja Karyawan Pada Kantor Pt. Pln (Persero) Area Pematangsiantar." SULTANIST: Jurnal Manajemen Dan Keuangan 3(2):33-41.

Ramadhan, Ahmad. 2017. "Pengaruh Pelaksanaan Supervisi Akademik Pengawas Sekolah Dan Supervisi Kepala Sekolah Terhadap Kinerja Guru SMK Negeri Di Kabupaten Majene." Journal of Educational Science and Technology (EST) 3(2):136.

Ramadona, Mohammad, and Rian Wibowo. 2016. "Pengaruh Supervisi Kepala Sekolah Terhadap Kinerja Guru Di Smp K 1 Penabur Pasar Baru Jakarta Pusat." Research and Development Journal of Education 3(1):27-34.

Rasyid, Mhd. Andi, and Hasrudy Tanjung. 2020. "Pengaruh Kompensasi, Lingkungan Kerja Dan Motivasi Terhadap Kepuasan Kerja Guru Pada SMA Swasta Perkumpulan Amal Bakti 4 Sampali Medan." Maneggio: Jurnal Ilmiah Magister Manajemen 3(1):60-74.

Ratnawati, Whina. 2018. "Pengaruh Kompensasi, Lingkungan Kerja, Dan Motivasi Kerja Terhadap Kinerja Guru Tidak Tetap." Jurnal Disrupsi Bisnis 1(2):156-68.

Rifaldi, Muhammad Ali, and Erny Roesminingsih. 2014. "Pengaruh Supervisi Kepala Sekolah Dan Motivasi Kerja Guru Terhadap Kepuasan Kerja Guru Di SMK ADB Invest Se-Kota Surabaya." Jurnal Inspirasi Manajemen Pendidikan 4(4):122-33.

Rismawan, Edi. 2015. "Pengaruh Supervisi Kepala Sekolah Dan Motivasi Berprestasi Guru Terhadap Kinerja Mengajar Guru." Jurnal Administrasi Pendidikan
22(1):114-32.

Risqon, Mochamad, and Didik Purwadi. 2012. "Pengaruh Kepemimpinan, Kompensasi Dan Kemampuan Kerja Terhadap Kinerja Karyawan." Daya Saing: Jurnal Ekonomi Manajemen Sumber Daya 13(1):35-43.

Robirodia, Zain I. J., and Eka Prihatin. 2016. "Pengaruh Kompensasi Dan Iklim Organisasi Sekolah Terhadap Kepuasan Kerja Guru Non PNS Madrasah Aliyah.” Jurnal Administrasi Pendidikan UPI 23(1):12-25.

Sarjana, Sri. 2012. "Pengaruh Supervisi Dan Iklim Organisasi Terhadap Kepuasan Kerja." Jurnal Kependidikan 42(2):17386.

Sarwono, J. 2016. Membuat Skripsi, Tesis Dan Disertasi Dengan Partial Least Square SEM (PLS - SEM). Yogyakarta: Andi Offset.

Sofyan, Soleh, Dodi Prasada, and Irfan Rizka Akbar. 2020. "Pengaruh Motivasi, Lingkungan Kerja Dan Kepuasan Kerja Terhadap Kinerja Guru SMP/MTs Muhammadiyah Cabang Sawangan." Jurnal Ilmu Komputer Dan Bisnis 11(2a):33-44.

Suhardi, and Erma Yunita. 2018. "Kompetensi Manajerial Kepala Sekolah, Kompensasi Dan Kepuasan Kerja Terhadap Kinerja Guru Pada SMK Swasta Di Kota Batam.” Coopetition: Jurnal Ilmiah Manajemen 9(1):35-46.

Suyusman, Omar Hendro, and Diah Isnaini Asiati. 2020. "Pengaruh Lingkungan Kerja Dan Kompensasi Serta Kepemimpinan Terhadap Kepuasan Kerja Guru Sekolah Menengah Pertama Negeri Kecamatan Rantau Panjang Kabupaten Ogan Ilir." Jurnal Manajemen Kompeten 3(1):89-109.

Syahputra, Linda, Darwin Lie, Parman Tarigan, and Efendi Efendi. 2013. "Pengaruh Kompensasi Terhadap Kinerja Karyawan Pada Perusahaan Mode Furniture Pematangsiantar." SULTANIST: Jurnal Manajemen Dan Keuangan 1(1):1-7.

Syamra, Yesmira. 2016. "Pengaruh Kompensasi Finansial Dan Motivasi Kerja Guru Terhadap Kinerja Guru Smk Negeri Pariwisata Di Kota Padang." Economica: Journal of Economic and Economic 
Educatio 4(2):258-68.

Virgana, Virgana. 2014. "Kepuasan Kinerja Guru Matematika Ditinjau Dari Pengaruh Supervisi Kepala Sekolah Dan Motivasi Kerja Guru." Formatif: Jurnal Ilmiah Pendidikan MIPA 4(1):11-20.

Wahyudi, Adi, Partono Thomas, and Rediana Setiyani. 2014. "Pengaruh Disiplin Kerja, Motivasi Kerja Dan Supervisi Kepala Sekolah Terhadap Kinerja Guru." Economic Education Analysis Journal 2(3):1-8.

Wardhani, E. W., and W. E. Soetomo. 2017. "Pengaruh Kepemimpinan Kepala Sekolah Danmotivasi Kerja Terhadap Kinerja Guru Dengan Kepuasan Kerja Guru Sebagai Variabel Mediasi Di Sma Negeri 11 Semarang." Jurnal Visi Manajemen 2(2):139-55.

Wibowo, S. A. 2014. "Hubungan Supervisi Kepala Sekolah Dan Motivasi Kerja Dengan Kepuasan Kerja Guru SD Di Kecamatan Pedurungan Kota Semarang." Jurnal Ilmiah Pendidikan Dasar 1(1):2031.
Widayati, Fatriani, Happy Fitria, and Yessi Fitriani. 2020. "Pengaruh Kepuasan Kerja Dan Loyalitas Kerja Terhadap Kinerja Guru." Journal of Education Research 1(3):251-57.

Wiguna, I. Made Angga, and IDG. Dharma Suputra. 2016. "Pengaruh Tindakan Supervisi, Pengalaman Kerja, Komitmen Organisasi, Dan Komitmen Profesional Terhadap Kepuasan Kerja Auditor." EJurnal Akuntansi Universitas Udayana 16(1):444-70.

Yohanas, Rian. 2018. "Pengaruh Supervisi Kepala Sekolah Dan Komunikasi Antar Pribadi Terhadap Kepuasan Kerja Guru Sd Negeri Se- Kecamatan Lima Kaum." AlFikrah: Jurnal Manajemen Pendidikan 6(1):33. 